\title{
The Location of Death and Dying Across Canada: A Study Illustrating the Socio-Political Context of Death and Dying
}

\author{
Donna M. Wilson ${ }^{1, *(\mathbb{D}}$, Ye Shen ${ }^{2}\left(\mathbb{D}\right.$, Begoña Errasti-Ibarrondo ${ }^{3(\mathbb{D}}$ and Stephen Birch ${ }^{4}$ \\ 1 Faculty of Nursing, University of Alberta, Edmonton, AB T6G 1C9, Canada \\ 2 School of Public Health, University of Alberta, Edmonton, AB T6G 2R3, Canada; yshen7@ualberta.ca \\ 3 Faculty of Nursing, University of Navarra, 31009 Pamplona, Spain; errastii@ualberta.ca \\ 4 Centre for the Business and Economics of Health, University of Queensland, Brisbane QLD 4072, Australia; \\ stephen.birch@uq.edu.au \\ * Correspondence: donna.wilson@ualberta.ca; Tel.: +1-(780)-492-5574
}

Received: 26 September 2018; Accepted: 6 November 2018; Published: 9 November 2018

\begin{abstract}
Background: Concern has existed for many years about the extensive use of hospitals by dying persons. In recent years, however, a potential shift out of hospital has been noticed in a number of developed countries, including Canada. In Canada, where high hospital occupancy rates and corresponding long waits and waitlists for hospital care are major socio-political issues, it is important to know if this shift has continued or if hospitalized death and dying remains predominant across Canada. Methods: Recent individual-anonymous population-level inpatient Canadian hospital data were analyzed to answer two questions: (1) what proportion of deaths in provinces and territories across Canada are occurring in hospital now? and (2) who is dying in hospital now? Results: In 2014-2015, 43.9\% of all deaths in Canada (excluding Quebec) occurred in hospital. However, considerable cross-Canada differences in end-of-life hospital utilization were found. Some cross-Canada differences in hospital decedents were also noted, although most were older, male, and they died during a relatively short hospital stay after being admitted from their homes and through the emergency department after arriving by ambulance. Conclusion: Over half of all deaths in Canada are occurring outside of hospital now. Cross-Canada hospital utilization and inpatient decedent differences highlight opportunities for enhanced end-of-life care service planning and policy advancements.
\end{abstract}

Keywords: hospital; death; aging; population data; hospital utilization; location of death; Canada

\section{Introduction}

For decades, concern has existed in Canada and many other countries over the extensive use of hospitals by terminally-ill and dying people [1]. One of the chief concerns is that most deaths take place in hospital and after an escalation in hospitalizations over the last year of life [1-4]. Not only has this end-of-life (EOL) hospital utilization raised care appropriateness and quality of care questions, but it has also raised major healthcare cost and opportunity cost issues such as the inaccessibility of hospital beds for uses other than palliative or EOL care [1-8]. In recent years, however, a potential shift out of hospital has been recognized in a number of developed countries, including Canada [9-11]. In Canada, where high hospital occupancy rates and subsequent long waits and waitlists for hospital care are serious socio-political issues, it is important to know if this shift out of hospital has continued or if hospitalized death and dying has remained predominant in all regions of Canada. To that end, recent Canadian hospital inpatient data were analyzed to answer two questions: (1) what proportion 
of deaths in provinces and territories across Canada are occurring in hospital now? and (2) who is dying in hospital now?

Canada is comprised of 10 provinces ranging across its southern regions and three territories spread across its northern regions, each of which is relatively autonomous is relation to planning and providing healthcare services. However, all must ensure reasonable access for all of their citizens to a wide range of publicly-funded and publicly-managed hospital and medical services in keeping with the 1984 Canada Health Act. Canada is the second largest country in the world, but sparsely populated with only 36.7 million citizens. The vast majority (around $80 \%$ ) of citizens live in cities and other urban areas, most of which are located near the southern border with the United States of America.

\section{Methods}

Comprehensive individual-anonymous population-level 2014-2015 Canadian hospital data (excluding stillbirths) were obtained for analysis upon request, the most recent year of data available in 2016 from the Canadian Institute for Health Information (CIHI). Their Discharge Abstracts Database (DAD) contains comprehensive socio-demographic, administrative, and clinical data on all hospital episodes taking place each fiscal year (1 April through $30 \mathrm{March}$ ) in every Canadian province and territory except Quebec. Quebec does not provide data to CIHI for comparative or other analyses. This database has reliable and valid data, derived from hospital chart abstract data that are submitted to $\mathrm{CIHI}$ and checked by CIHI for completeness and accuracy, with minimal or no missing data for each variable.

Inpatient decedent characteristics, numbers of deaths, and other hospital utilization descriptors of decedents including cause of death were extracted from the DAD database. The data were stratified and presented by province or territory using the statistical summary functions of the SPSS (version 23) program. Research ethics approval was obtained in advance of this data analysis from the University of Alberta's Health Research Ethics Board (\#Pro00063626).

\section{Results}

As outlined in a previous research overview publication [12], 1,864,730 admissions to hospitals across Canada (excluding Quebec) occurred in the 2014-2015 year and 88,100 (3.5\%) of these admissions ended in death. With a total of 200,614 deaths occurring in the 2014-2015 year across Canada outside of Quebec [13], these hospital deaths represent $43.9 \%$ of all deaths that year. However, as shown in Table 1, considerable variance in the proportion of deaths occurring in hospital were noted across the three sparsely populated northern territories (i.e., Yukon Territory, Northwest Territories, and Nunavut) as well as across the nine more heavily populated and more extensively urbanized provinces. Hospital deaths ranged from only $6.6 \%$ of total deaths in the Yukon Territory to $15.2 \%$ in the Northwest Territories, and from $40.9 \%$ of total deaths in the province of British Columbia to $57.0 \%$ in the province of New Brunswick. As such, the proportion of provincial or territorial deaths occurring in hospital was consistently much higher in the provinces than the three territories across the northern regions of Canada.

As shown in Table 2, the people who died in hospital were more often older and male, and they died after a relatively short hospital stay with a diagnosis most commonly of "factors influencing health status and contact with the healthcare system". This diagnosis indicates no specific illness that is potentially treatable is present. It is often used for patients nearing an inevitable death and who are thus appropriate recipients for palliative care.

Moreover, patients who died in hospital were most often admitted to hospital from their homes or private residences $(69.6 \%)$, after having been admitted through the emergency department $(79.0 \%)$ and following an arrival by ambulance (70.5\%). Although $29.2 \%$ of all hospital deaths occurred in or after admission to a special care unit (such as an Intensive Care Unit (ICU) or Coronary Care Unit (CCU)), less than $1 \%$ of hospital decedents died during an intervention (such as cardiopulmonary resuscitation or surgery). 
Table 1. Hospital deaths across Canada as a proportion of total deaths (2014-2015).

\begin{tabular}{cccc}
\hline Region of Canada & Total Deaths-All Places $(\boldsymbol{N})$ & In-Hospital Deaths $(\boldsymbol{N})$ & In-Hospital Deaths (\%) \\
\hline Province & & & \\
\hline Alberta (AB) & 24,164 & 10,521 & 43.5 \\
British Columbia (BC) & 34,652 & 14,177 & 40.9 \\
Manitoba (MN) & 10,503 & 5403 & 51.5 \\
New Brunswick (NB) & 6870 & 3921 & 57.0 \\
Newfoundland and Labrador & 4943 & 2523 & 51.0 \\
(NL) & 8854 & 4775 & 53.9 \\
Nova Scotia (NS) & 99,231 & 41,304 & 41.6 \\
Ontario (ON) & 1296 & 665 & 51.3 \\
Prince Edward Island (PEI) & 9482 & 4427 & 46.7 \\
Saskatchewan (SK) & & & 8.5 \\
\hline Territory & 222 & 19 & 15.2 \\
\hline Northwest Territories (NWT) & 171 & 26 & 6.6 \\
Nunavut (NU) & 226 & 15 & 43.8 \\
Yukon Territory (YT) & 200,614 & $87,776^{*}$ & \\
\hline Total Deaths &
\end{tabular}

* 324 patients who died in hospital were not defined by province or territory.

Table 2. Decedent final stay hospital utilization and patient characteristics (2014-2015).

\begin{tabular}{|c|c|c|c|}
\hline Variable & $\begin{array}{c}\text { All Territories and Provinces } \\
\text { Combined }\end{array}$ & $\begin{array}{l}\text { Low Outliers (Territory } \\
\text { and Provincial) }\end{array}$ & $\begin{array}{c}\text { High Outliers (Territory } \\
\text { and Provincial) }\end{array}$ \\
\hline Age (years) & 75.1 (mean)/79 (median) & $\begin{array}{l}54.0 / 58.5(\mathrm{NU}) \\
72.8 / 77.0(\mathrm{AB})\end{array}$ & $\begin{array}{l}64.7 / 65.0(\mathrm{YT}) \\
76.5 / 78.0(\mathrm{NB})\end{array}$ \\
\hline Gender (male) & $52.9 \%$ & $\begin{array}{l}53.8 \%(\mathrm{NU}) \\
49.3 \%(\mathrm{PEI})\end{array}$ & $\begin{array}{c}63.2 \%(\mathrm{NWT}) \\
64.9 \%(\mathrm{BC})\end{array}$ \\
\hline Direct admission to hospital & $18.8 \%$ & $\begin{array}{l}15.4 \%(\mathrm{NU}) \\
15.7 \%(\mathrm{BC})\end{array}$ & $\begin{array}{l}63.2 \%(\mathrm{NWT}) \\
29.7 \%(\mathrm{MN})\end{array}$ \\
\hline Admitted through the ER & $79.0 \%$ & $\begin{array}{c}36.8 \%(\mathrm{NWT}) \\
67.4 \%(\mathrm{MN})\end{array}$ & $\begin{array}{l}84.6 \%(\mathrm{NU}) \\
83.0 \%(\mathrm{BC})\end{array}$ \\
\hline Ambulance arrival & $70.5 \%$ & $\begin{array}{l}65.4 \%(\mathrm{NU}) \\
54.0 \%(\mathrm{MB})\end{array}$ & $\begin{array}{c}89.5 \%(\mathrm{NWT}) \\
75.0 \%(\mathrm{NF})\end{array}$ \\
\hline $\begin{array}{l}\text { At home without home care } \\
\text { services prior to final stay }\end{array}$ & $67.0 \%$ & $\begin{array}{c}15.8 \%(\mathrm{NWT}) \\
61.0 \%(\mathrm{AB})\end{array}$ & $\begin{array}{l}65.4 \%(\mathrm{NU}) \\
72.9 \%(\mathrm{BC})\end{array}$ \\
\hline $\begin{array}{l}\text { At home with home care services } \\
\text { prior to final stay }\end{array}$ & $3.6 \%$ & $\begin{array}{c}0 \text { (NWT, YT, NU) } \\
0(\mathrm{NL})\end{array}$ & $\begin{array}{c}0 \text { (NWT, YT, NU) } \\
11.0 \% \text { (NS) }\end{array}$ \\
\hline At nursing home prior to final stay & $6.2 \%$ & $\begin{array}{c}0 \text { (NWT, YT, NU) } \\
0.8 \%(\mathrm{NL})\end{array}$ & $\begin{array}{c}0 \text { (NWT, YT, NU) } \\
9.0 \% \text { (PEI) }\end{array}$ \\
\hline $\begin{array}{l}\text { At another acute care hospital } \\
\text { prior to final stay }\end{array}$ & $9.3 \%$ & $\begin{array}{c}26.9 \%(\mathrm{NU}) \\
6.9 \%(\mathrm{ON})\end{array}$ & $\begin{array}{l}68.4 \%(\mathrm{NWT}) \\
20.1 \%(\mathrm{SK})\end{array}$ \\
\hline $\begin{array}{l}\text { Total hospital stay-acute and } \\
\text { alternative level of care (days) }\end{array}$ & 16.4 (mean) (7 median) & $\begin{array}{l}15.1 / 10(\mathrm{YT}) \\
13.9 / 6(\mathrm{ON})\end{array}$ & $\begin{array}{l}16.7 / 7(\mathrm{NWT}) \\
26.5 / 9(\mathrm{NB})\end{array}$ \\
\hline $\begin{array}{l}\text { Alternative level of care stay } \\
\text { component (days) }\end{array}$ & 2.0 (mean) (0 median) & $\begin{array}{c}0.0 / 0(\mathrm{YT} / \mathrm{NWT}) \\
1.0 / 0(\mathrm{SK})\end{array}$ & $\begin{array}{l}0.3 / 0(\mathrm{NU}) \\
8.8 / 0(\mathrm{NB})\end{array}$ \\
\hline $\begin{array}{l}\text { Length of special care unit } \\
\text { stay (hours) }\end{array}$ & 135.4 (mean) (62 median) & $\begin{array}{l}119.1 / 77.0(\mathrm{YT}) \\
111.4 / 53.0(\mathrm{SK})\end{array}$ & $\begin{array}{l}244.9 / 95.0(\mathrm{NU}) \\
143.9 / 63.0(\mathrm{ON})\end{array}$ \\
\hline $\begin{array}{l}\text { Death in a special care } \\
\text { unit (ICU/CCU) }\end{array}$ & $29.2 \%$ & $\begin{array}{l}42.3 \% \text { (NU) } \\
11.8 \% \text { (NS) }\end{array}$ & $\begin{array}{l}73.3 \%(\mathrm{YT}) \\
24.5 \%(\mathrm{ON})\end{array}$ \\
\hline Died during an intervention & $0.8 \%$ & $\begin{array}{c}\text { missing } \\
0.2 \% \text { (NS) }\end{array}$ & $\begin{array}{c}\text { missing } \\
2.6 \% \text { (PEI) }\end{array}$ \\
\hline Preadmission flag & $4.9 \%$ & $\begin{array}{c}10.5 \%(\mathrm{NWT}) \\
1.1 \%(\mathrm{NB})\end{array}$ & $\begin{array}{l}13.3 \%(\mathrm{YT}) \\
5.9 \%(\mathrm{ON})\end{array}$ \\
\hline $\begin{array}{l}\text { Most frequent final } \\
\text { primary diagnosis }\end{array}$ & FAHS and CHS * $24.6 \%$ & $\begin{array}{c}0(\mathrm{NWT}) \\
21.1 \%(\mathrm{ON})\end{array}$ & $\begin{array}{l}15.4 \% \text { (NU) } \\
42.4 \% \text { (NS) }\end{array}$ \\
\hline $\begin{array}{l}\text { Second most frequent final } \\
\text { primary diagnosis }\end{array}$ & Circulatory disorders $18.6 \%$ & $\begin{array}{l}7.2 \%(\mathrm{NU}) \\
14.1 \%(\mathrm{NS})\end{array}$ & $\begin{array}{c}36.8 \%(\mathrm{NWT}) \\
21.4 \%(\mathrm{PEI})\end{array}$ \\
\hline
\end{tabular}


Table 2. Cont.

\begin{tabular}{cccc}
\hline Variable & $\begin{array}{c}\text { All Territories and Provinces } \\
\text { Combined }\end{array}$ & $\begin{array}{c}\text { Low Outliers (Territory } \\
\text { and Provincial) }\end{array}$ & $\begin{array}{c}\text { High Outliers (Territory } \\
\text { and Provincial) }\end{array}$ \\
\hline $\begin{array}{c}\text { Third most frequent final } \\
\text { primary diagnosis }\end{array}$ & Respiratory disorders 15.2\% & 0 (NWT) & $6.7 \%(\mathrm{YT})$ \\
$12.2 \%(\mathrm{NS})$ & $6.7 \%(\mathrm{YT})$ & $26.3 \%(\mathrm{NWT})$ \\
\hline $\begin{array}{c}\text { Fourth most frequent final } \\
\text { primary diagnosis }\end{array}$ & Neoplasms 9.6\% & $7.2 \%(\mathrm{NL} / \mathrm{NS})$ & $12.0 \%(\mathrm{PEI})$ \\
\hline
\end{tabular}

* Factors affecting health status and contact with the healthcare system.

Regardless, considerable cross-Canada differences in the characteristics of patients who died in hospital were noted. Moreover, considerable cross-Canada differences in EOL hospital utilization were noted. Table 2 contains outlier findings for the territories and provinces of Canada (excluding Quebec), with these outlier findings presented to demonstrate the wide range of province to province and territory to territory, as well as province to territory differences.

\section{Discussion}

This study clearly reveals that hospitals are no longer the predominant place of death and dying in Canada as a whole (excluding Quebec, as no data from this province were available for analysis), with only $43.9 \%$ of all deaths occurring in hospital in the fiscal year of 2014-2015. This finding is in stark contrast to the peak rate of $80.5 \%$ in the 1994 calendar year [14]. As the majority of deaths in Canada occurred in hospital for many years before and after 1994 [10], this pronounced shift of death and thus also dying and EOL care out of hospital is remarkable. Moreover, this shift is remarkable, if not highly unusual, as it occurred without any specific enabling national political or other national plan to encourage and support death and dying outside of hospital.

This substantial reduction in the proportion of total deaths occurring in hospital is not exclusive to Canada. As indicated, many other developed countries are experiencing a shift out of hospital, with an increasing proportion of deaths if not the majority of deaths occurring in other places such as nursing homes and private or primary residences [5,8,9,15-17]. The reduction in these countries in both the apparent need for and the resultant use of hospitals for EOL care purposes has been associated with enhanced and more accessible palliative home care services, nursing home expansion and onsite nursing home EOL care advancements, and increased or sustained government funding for free-standing hospices $[5,8,9,15-17]$.

It is therefore notable that the Canadian province of British Columbia, which had the lowest percentage of hospital deaths among the provinces at $40.9 \%$, has had a province-wide EOL care plan since 2013 [18]. This plan followed a 2006 EOL care policy that was designed to support the planning of EOL primary care and other community-based EOL care options [18]. This policy and subsequent planning might explain why more people in that province die in place and without the apparent need for hospital admission and inpatient EOL care.

It is also possible that palliative care advancements over the last two decades in British Columbia and elsewhere across Canada have been influential for this shift of death and thus also EOL care out of hospital, as advancements in palliative knowledge, skills, equipment, and services have been considerable in recent years. Indeed, a recent literature review identified palliative care developments as one of three primary influences for deaths to be increasingly taking place outside of Canadian hospitals [19]. Another influence was determined to be a reduction in the actual availability of hospital beds as a consequence of cross-Canada hospital bed closures, coupled with the reduced social desirability of hospital-based EOL care [19]. The third influence was identified as recent socio-demographic developments, notably population aging, increased multiculturalism, and more social acceptance of dying - all of which have contributed to a greater diversity in accepted EOL care practices as well as a change the general public's EOL care preferences [19]. It is well established now that most people would prefer to die at home, if they have that choice available to them [20]. 
These are remarkable influences given the increasing number of deaths and increasing proportion of deaths that were occurring in Canadian hospitals each year from at least 1950, if not before, through to 1994 [21]. This hospitalization trend is thought to have been due to major cross-Canada hospital construction and modernization developments that made hospitals more accessible as well as more socially acceptable. At the same time, changing family structures, such as women increasingly working outside of the home, made EOL care in the home much less possible [21].

More recently, the 2015 Health Accord in Canada, a policy promise made by a political party that was subsequently elected to become the current reigning federal government of Canada, mandated that a higher proportion of the federal funding transfer to the provinces and territories for healthcare was to be used to expand home care services. This political promise, with directed funding increases for home care over the four-year political term of 2015 to 2019, may prove to be a significant factor for supporting and sustaining the shift of death and dying out of hospital [22]. The need for more palliative home care services was made clearly evident by this study, as of all admissions to hospital that ended in death, only $3.6 \%$ were from homes receiving publicly-funded home care services. In contrast, $67.0 \%$ of admissions to hospital ending in death were from homes where no publicly-funded home care services were provided. This is not the first time that the need for more palliative home care has been identified in Canada [23]. Moreover, a growing body of evidence is demonstrating the effectiveness of palliative home care services for stabilizing the dying process through meeting existing and emerging EOL care needs, while simultaneously reducing EOL hospital admissions and emergency department utilization [24].

As such, the greatest need for high quality EOL care now appears to be enhanced home-based support so more deaths can take place at home and in ways that meet the needs of both the dying person and their family caregivers. However, some gender considerations appear to be relevant to consider, as we found that with the exception of Prince Edward Island, males were more often admitted to hospital to die there as compared to females. This gender difference suggests the need for better targeting of home care services. Unfortunately, the Canadian hospital database does not report marital status. However, it may be that the higher proportion of males dying in hospital is associated with unmarried, divorced, and widowed men not having spousal or other family support available to them when they are dying. It is also possible that hospital deaths are high among married men with spouses, the most common informal care provider [25]. Spouses may reach a point where they can no longer provide unsupported EOL care at home; informal caregiver overburden is a well-established and long-standing issue in Canada [26].

This study surprisingly revealed that cancer is not a major factor for hospitalized death, as under $10 \%$ of all hospital decedents were diagnosed with cancer. As cancer has been the most common cause of death in Canada for at least two decades, and it remains the most common cause of death now in Canada [27], it will be important to determine why many of those diagnosed with terminal cancer are dying outside of hospital now. However, research, policy, and practice attention should be aimed at the majority of people who are dying in hospital; those with end-stage circulatory and end-stage respiratory illnesses, and also those with the non-specific International Statistical Classification of Diseases and Related Health Problems (ICD-10) Chapter XXI diagnosis of "factors influencing health status and contact with health services". The identified diversity across provinces and territories in relation to these terminal diagnoses and their related EOL hospital utilization indicates that each province and territory should develop their own EOL care strategies to support people diagnosed with these illnesses so they are appropriately cared for in place.

Concerted cross-Canada attention also needs to be focused on people diagnosed with "factors influencing health status and contact with health services", the most common diagnosis among all hospital decedents. As mentioned above, this diagnosis indicates that no specific illness exists that is potentially treatable, and it is often given to patients who are close to death, a time when palliative care is appropriate. Non-hospital deaths should be possible for all persons with this diagnosis. 
With the exception of deaths taking place in special care units such as the ICU and CCU, where efforts to save life are likely to be appropriately attempted in most if not all cases [28], the predominance of hospital deaths occurring after an ambulance arrival and an emergency department visit indicates that a potentially avoidable health crisis or family caregiver crisis led to a hospital death. With a relatively short median final hospital stay of only 7 days, this also indicates that short-term intensive palliative support at home or in other non-hospital places such as nursing homes may not only avert the need for hospital-based EOL care but also prevent these crises. This emphasis on preventing crises is timely, as the vast majority of deaths in Canada and most other developed countries are not sudden or unexpected now [29]. High quality EOL care over the dying trajectory is thus increasingly possible to plan for. The use of flags in hospital databases to identify people who are nearing the end of life may be a necessary first step.

\section{Conclusions}

This study of recent population-level hospital data revealed that only $3.5 \%$ of admissions to hospital in the 2014-2015 year ended in death and only 43.9\% of all deaths that year in Canada (excluding Quebec) occurred in hospital. As such, a major shift of death and dying out of hospital has occurred in Canada since 1994, when hospital deaths peaked at 80.5\% [10], but with considerable cross-Canada differences in EOL hospital utilization identified. These differences, in addition to the differing characteristics of hospital decedents, present evidence that will help in planning EOL service improvements and advancing EOL policy to address the needs of current and future populations. Such investments offer prospects of improved well-being for patients and families throughout the dying process, as well as a reduction in healthcare system costs and opportunity costs.

Author Contributions: Conceptualization, D.M.W. and S.B.; Formal analysis, Y.S.; Funding acquisition, D.M.W. and S.B.; Investigation, D.M.W.; Methodology, S.B.; Software, Y.S.; Supervision, D.M.W.; Validation, B.E.-I.; Writing-original draft, D.M.W. and S.B.; Writing-review and editing, D.M.W., Y.S., B.E.-I., and S.B.

Funding: This research was funded by Law Commission of Ontario research grant.

Conflicts of Interest: The authors declare no financial or ethical conflict of interest.

\section{References}

1. Scitovsky, A.A. The high cost of dyin: What do the data show? Milbank Q. 2005, 83, 825-841. [CrossRef] [PubMed]

2. Trachtenberg, A.J.; Manns, B. Cost analysis of medical assistance in dying in Canada. Can. Med. Assoc. J. 2017, 189, E101-E105. [CrossRef] [PubMed]

3. Menec, V.; Lix, L.; Nowicki, S.; Ekuma, O. Health care use at the end of life among older adults: Does it vary by age? J. Gerontol. A Biol. Sci. Med. Sci. 2007, 62, 400-407. [CrossRef] [PubMed]

4. Tanuseputro, P.; Wodchis, W.P.; Fowler, R.; Walker, P.; Bai, Y.Q.; Bronskill, S.E.; Manuel, D. The health care cost of dying: A population-based retrospective cohort study of the last year of life in Ontario, Canada. PLoS ONE 2015, 10, e0121759. [CrossRef] [PubMed]

5. Houttekier, D.; Cohen, J.; Pepersack, T.; Deliens, L. Dying in hospital: A study of incidence and factors related to hospital death using death certificate data. Eur. J. Public Health 2014, 24, 751-756. [CrossRef] [PubMed]

6. Pot, A.M.; Portrait, F.; Visser, G.; Puts, M.; van Groenou, M.I.; Deeg, D.J. Utilization of acute and long-term care in the last year of life: Comparison with survivors in a population-based study. BMC Health Serv. Res. 2009, 9, 139. [CrossRef] [PubMed]

7. Thurston, A.J.; Wilson, D.M.; Hewitt, J.A. Current end-of-life care needs and care practices in acute care hospitals. Nurs. Res. Pract. 2012, 869303. Available online: https://www.hindawi.com/journals/nrp/2011/ 869302/ (accessed on 8 November 2018).

8. Moens, K.; Houttekier, D.; Van den Block, L.; Harding, R.; Morin, L.; Marchetti, S.; Csikos, A.; Loucka, M.; Naylor, W.A.; Wilson, D.M.; et al. Place of death of people living with Parkinson's disease: A population-level study in 11 countries. BMC Palliat. Care 2015, 14, 28. [CrossRef] [PubMed] 
9. Teno, J.M.; Gozalo, P.L.; Bynum, J.P.; Leland, N.E.; Miller, S.C.; Morden, N.E.; Scupp, T.; Goodman, D.C.; Mor, V. Change in end-of-life care for Medicare beneficiaries: Site of death, place of care, and health care transitions in 2000, 2005, and 2009. JAMA 2013, 309, 470-477. [CrossRef] [PubMed]

10. Wilson, D.M.; Truman, C.D.; Thomas, R.; Fainsinger, R.; Kovacs-Burns, K.; Froggatt, K.; Justice, C. The rapidly changing location of death in Canada, 1994-2004. Soc. Sci. Med. 2009, 68, 1752-1758. [CrossRef] [PubMed]

11. Gao, W.; Ho, Y.K.; Verne, J.; Glickman, M.; Higginson, I.J. Changing patterns in place of cancer deaths in England: A population-based study. PLoS Med. 2013, 10, e1001410. [CrossRef] [PubMed]

12. Wilson, D.M.; Shen, Y.; Birch, S. New evidence on end-of-life hospital utilization for enhanced health policy and services planning. J. Palliat. Med. 2017, 20, 752-758. [CrossRef] [PubMed]

13. Statistics Canada. Deaths, Estimates, by Province and Territory, CANSIM [Table 051-0004 and Cat. 91-215-X]; Statistics Canada: Ottawa, ON, Canada, 2015.

14. Wilson, D.M.; Northcott, H.C.; Truman, C.D.; Smith, S.L.; Anderson, M.C.; Fainsinger, R.L.; Stingl, M.J. Location of death in Canada: A comparison of 20th-century hospital and nonhospital locations of death and corresponding population trends. Eval. Health Prof. 2001, 24, 385-403. [CrossRef] [PubMed]

15. Cohen, J.; Pivodic, L.; Miccinesi, G.; Onwuteaka-Philipsen, B.D.; Naylor, W.A.; Wilson, D.M.; Loucka, M.; Csikos, A.; Pardon, K.; Van den Block, L.; et al. International study of the place of death of people with cancer: A population-level comparison of 14 countries across 4 continents using death certificate data. Br. J. Cancer 2015, 113, 1397-1404. [CrossRef] [PubMed]

16. Pivodic, L.; Pardon, K.; Morin, L.; Addington-Hall, J.; Miccinesi, G.; Cardenas-Turanzas, M.; Onwuteaka-Philipsen, B.; Naylor, W.; Ramos, M.R.; Van den Block, L.; et al. Place of death in the population dying from diseases indicative of palliative care need: A cross-national population-level study in 14 countries. J. Epidemiol. Commun. Health 2016, 70, 17-24. [CrossRef] [PubMed]

17. Reyniers, T.; Deliens, L.; Pasman, H.R.; Morin, L.; Addington-Hall, J.; Frova, L.; Cardenas-Turanzas, M.; Onwuteaka-Philipsen, B.; Naylor, W.; Ruiz-Ramos, M.; et al. International variation in place of death of older people who died from dementia in 14 European and non-European countries. J. Am. Med. Dir. Assoc. 2015, 16, 165-171. [CrossRef] [PubMed]

18. Ministry of Health. The Provincial End-of-Life Care Action Plan for British Columbia; Ministry of Health: Victoria, BC, Canada, 2013.

19. Wilson, D.M.; Hewitt, J.A.; Thomas, R.E.; Woytowich, B. Why did an out-of-hospital shift of death and dying occur in Canada after 1994? Int. J. Palliat. Care 2014, 2014, 157536. [CrossRef]

20. Wilson, D.M.; Cohen, J.; Deliens, L.; Hewitt, J.A.; Houttekier, D. The preferred place of last days: Results of a representative population-based public survey. J. Palliat. Med. 2013, 16, 502-508. [CrossRef] [PubMed]

21. Wilson, D.M.; Smith, S.L.; Anderson, M.C.; Northcott, H.C.; Fainsinger, R.L.; Stingl, M.J.; Truman, C.D. Twentieth-century social and health-care influences on location of death in Canada. Can. J. Nurs. Res. 2002, 34, 141-161. [PubMed]

22. Liberal Party of Canada. A New Health Accord; Liberal Party of Canada: Ottawa, ON, Canada, 2017.

23. Wilson, D.M.; Truman, C.; Huang, J.; Sheps, S.; Birch, S.; Thomas, R.; Noseworthy, T. Home care evolution in Alberta: How have palliative clients fared? Healthc. Policy J. 2007, 2, 44-56. [CrossRef]

24. Seow, H.; Brazil, K.; Sussman, J.; Pereira, J.; Marshall, D.; Austin, P.C.; Husain, A.; Rangrej, J.; Barbera, L. Impact of community based, specialist palliative care teams on hospitalizations and emergency department visits late in life and hospital deaths: A pooled analysis. BMJ 2014, 348, 1-10. [CrossRef] [PubMed]

25. Turcotte, M. Family Caregiving: What are the Consequences? Statistics Canada: Ottawa, ON, Canada, 2015.

26. Sinha, M. Portrait of Caregivers, 2012; Statistics Canada: Ottawa, ON, Canada, 2015.

27. Canadian Cancer Society. Cancer Statistics at a Glance; Canadian Cancer Society: Ottawa, ON, Canada, 2017.

28. Kramer, A.A.; Higgins, T.L.; Zimmerman, J.E. The association between ICU readmission rate and patient outcomes. Crit. Care Med. 2013, 4, 24-33. [CrossRef] [PubMed]

29. Statistics Canada. Mortality Overview: 2001 and 2011; Statistics Canada: Ottawa, ON, Canada, 2015.

(C) 2018 by the authors. Licensee MDPI, Basel, Switzerland. This article is an open access article distributed under the terms and conditions of the Creative Commons Attribution (CC BY) license (http:/ / creativecommons.org/licenses/by/4.0/). 